\title{
Reduction Kinetics of Uranium Trioxide to Uranium Dioxide Using Hydrogen
}

\author{
Pedro Orrego Alfaro1, José Hernández Torres', Fernando Puchi Thiele² \\ ${ }^{1}$ Sección de Geología y Minería, Departamento de Materiales Nucleares, Comisión Chilena de Energía Nuclear, \\ Santiago, Chile \\ ${ }^{2}$ Ingeniería Civil Metalurgia, Universidad Andrés Bello, Santiago, Chile \\ Email: porrego@cchen.cl, jihernandez@cchen.cl, fernando.puchi@unab.cl
}

Received 24 April 2015; accepted 6 July 2015; published 9 July 2015

Copyright (C) 2015 by authors and Scientific Research Publishing Inc.

This work is licensed under the Creative Commons Attribution International License (CC BY). http://creativecommons.org/licenses/by/4.0/

(c) (i) Open Access

\section{Abstract}

This article presents a study on the kinetics of the uranium conversion process, consisting in the reduction of uranium trioxide to uranium dioxide using hydrogen gas at temperatures of $500^{\circ} \mathrm{C}$, $600^{\circ} \mathrm{C}$ and $700^{\circ} \mathrm{C}$. Hydrogen concentrations used in the flow were $0.25 \mathrm{M}, 0.50 \mathrm{M}$ and $0.75 \mathrm{M}$. The mechanism established for the study of the kinetics of reduction of uranium trioxide was through the formation of an intermediate compound, $\mathrm{U}_{3} \mathrm{O}_{8}$. For this reason, these tests were divided into 2 stages: the first one the reduction from $\mathrm{UO}_{3}$ to $\mathrm{U}_{3} \mathrm{O}_{8}$, and second one from $\mathrm{U}_{3} \mathrm{O}_{8}$ to $\mathrm{UO}_{2}$. The results of each test were quantified by the release of $\mathrm{H}_{2} \mathrm{O}_{(\mathrm{g})}$ produced by both reactions. Tests showed that the ideal working conditions are for hydrogen concentration flows of $0.75 \mathrm{M}$ and temperatures in the range of $500^{\circ} \mathrm{C}-600^{\circ} \mathrm{C}$, with the intent to decrease the occurrence of side reactions that interfere with the process.

\section{Keywords}

Conversion, Uranium Oxides, Nuclear Fuel Cycle

\section{Introduction}

One of the most important energy sources for the development of the worldwide industry is from nuclear fuels. Uranium is used in power reactors as natural uranium for the development of other fuel elements alloys or as $\mathrm{UO}_{2}$ pellets. The most important condition for its use in these applications is the impurity level, especially boron and cadmium, which cannot be more than 0.2 to $300 \mu \mathrm{g} / \mathrm{g}$ respectively, because they decrease fuel efficiency. For this purpose, uranium concentrate must be purified for the manufacture of the fuel element [1].

The purification process for uranium concentrate is shown in Figure 1. 


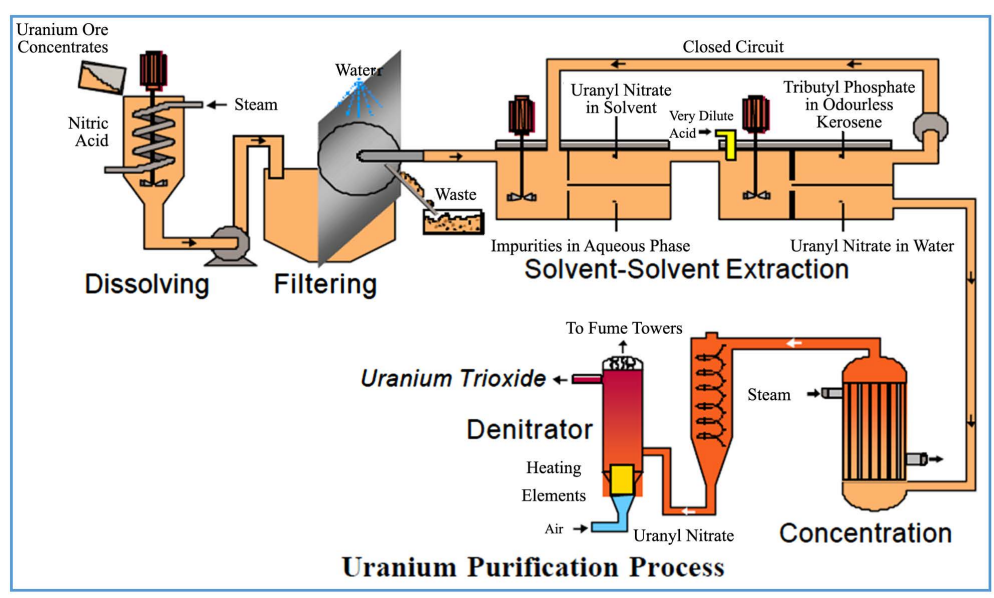

Figure 1. Purification process of uranium concentrates [2].

The purification process in Figure 1 consists in the oxidizing dissolution of uranium concentrate, which may be ammonium diuranate (ADU) or ammonium uranyl carbonate (AUC), by using nitric acid, to ensure that all uranium is dissolved. Subsequently, the uranyl nitrate solution is treated by using solvent extraction techniques. At this stage, the latter compound is selectively extracted by the organic reagent tributyl phosphate (TBP), and subsequently discharged onto a water flow at $60^{\circ} \mathrm{C}$, to precipitate it as ADU or AUC. Finally, the precipitate must be calcined to produce $\mathrm{UO}_{3}[2]$ [3].

The conversion process from Figure 2 consists in the reduction of $\mathrm{UO}_{3}$ to $\mathrm{UO}_{2}$ using hydrogen gas at high temperatures. Finally, in order to obtain metallic uranium, the $\mathrm{UO}_{2}$ compound goes to hydrofluorination stage, where it contacts hydrogen fluoride to produce $\mathrm{UF}_{4}$ and obtain fuel elements [2].

From Figure 1 and Figure 2, most of the sub stages have well-defined reaction mechanisms. From these, the stage that causes most controversy in these terms is the conversion of uranium trioxide $\left(\mathrm{UO}_{3}\right)$ to uranium dioxide $\left(\mathrm{UO}_{2}\right)$. The reason for this problem is the large amount of uranium compounds formed during $\mathrm{UO}_{3}$ reduction using hydrogen gas at temperatures between $500^{\circ} \mathrm{C}$ and $700^{\circ} \mathrm{C}$. The most known oxidized uranium compounds that may formare $\mathrm{U}_{3} \mathrm{O}_{8}, \mathrm{U}_{3} \mathrm{O}_{7}$ and $\mathrm{U}_{4} \mathrm{O}_{9}$, which have different oxidation states at their nets, and they are able to affect in several ways the conversion process [4].

It is for these reasons that this article will study the kinetics of reduction from uranium trioxide to uranium dioxide with hydrogen, together with the influence of each parameter on the overall process.

The conversion process consists in the reduction reaction of uranium trioxide to uranium dioxide according to Equation (1): [5] [6]

$$
\mathrm{UO}_{3}+\mathrm{H}_{2}=\mathrm{UO}_{2}+\mathrm{H}_{2} \mathrm{O}
$$

Figure 3 shows the uranium Pourbaix diagram:

According to Figure 3, before the uranium trioxide is reduced to uranium dioxide, it will show up a third oxide species, $\mathrm{U}_{3} \mathrm{O}_{8}$. This sub process is shown in reaction (2): [5] [6]

$$
3 \mathrm{UO}_{3}+\mathrm{H}_{2}=\mathrm{U}_{3} \mathrm{O}_{8}+\mathrm{H}_{2} \mathrm{O}
$$

Once formed this compound, it is from $\mathrm{U}_{3} \mathrm{O}_{8}$ that uranium dioxide is formed by hydrogen reduction, according to reaction (3): [5] [6]

$$
\mathrm{U}_{3} \mathrm{O}_{8}+2 \mathrm{H}_{2}=3 \mathrm{UO}_{2}+2 \mathrm{H}_{2} \mathrm{O}
$$

This process is normally carried out at temperatures above $500^{\circ} \mathrm{C}$, since, as shown in Figure 3, it is possible to obtain the $\mathrm{UO}_{2}$ using manganese oxides [7] or reducing agents such as iron and bacterial enzymes [8]. However, according to the Pourbaix diagram, $\mathrm{UO}_{2}$ precipitates at wide $\mathrm{pH}$ ranges. At room temperature, impure products can precipitate, because besides uranium precipitation, other oxides of many elements, especially iron, would precipitate. Temperatures over $500^{\circ} \mathrm{C}$ during the process will prevent the occurrence of parasitic reactions that could contaminate the final $\mathrm{UO}_{2}$ concentrate.

The importance of this work arises from the need of knowledge of the reaction mechanism for the develop- 


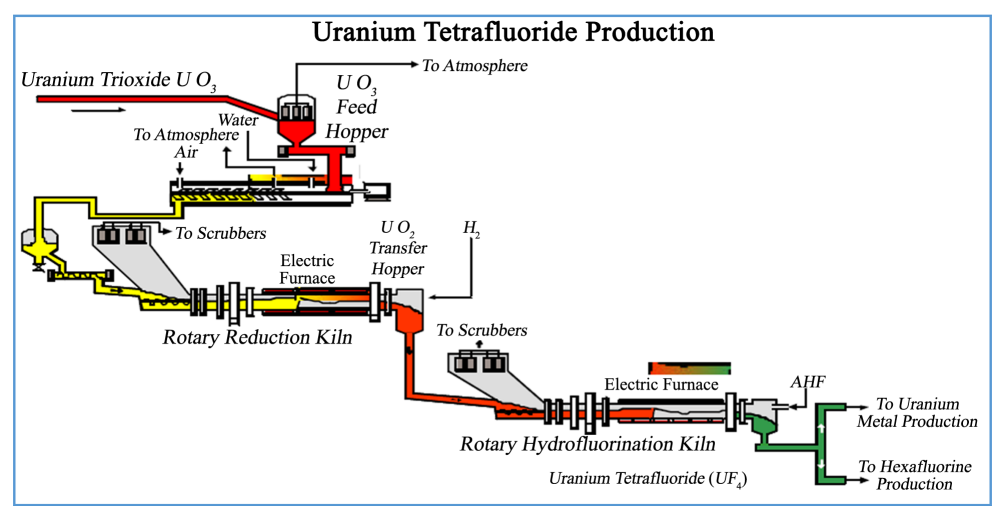

Figure 2. $\mathrm{UF}_{4}$ production from $\mathrm{UO}_{3}$ by hydrofluorination [2].

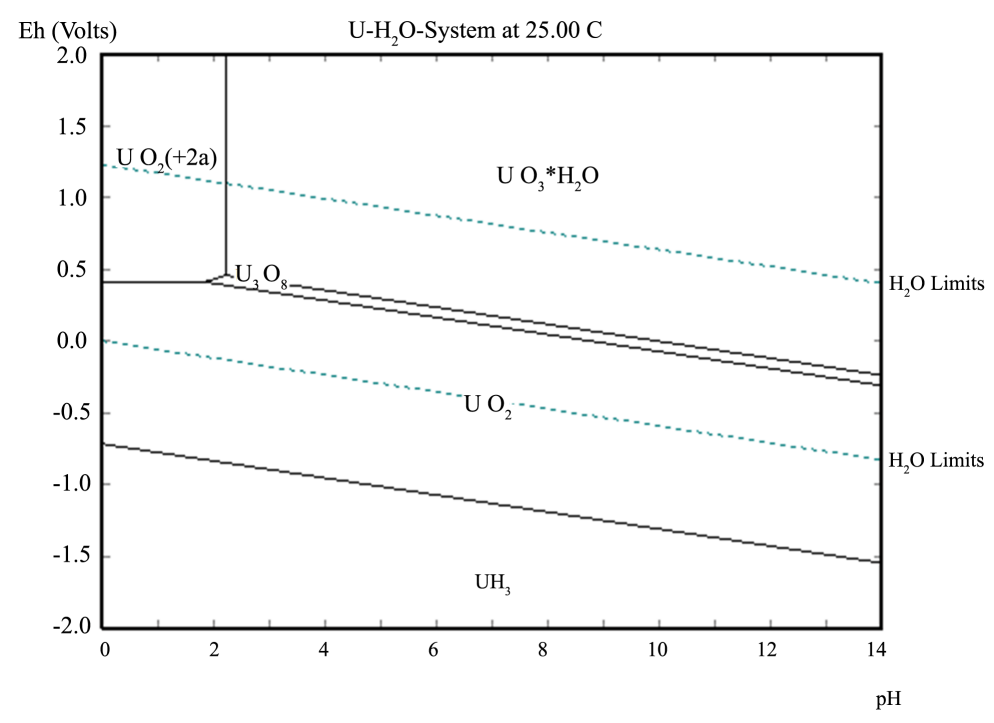

Figure 3. Uranium Pourbaixdiagram [4].

ment of a new reactor, capable of the calcination of different uranium concentrates and reducing them directly to uranium dioxide.

Thus, the study of this process was performed for the study of reactions (2) and (3) in separate ways.

\section{Experimental Development}

The experimental setup is shown in Figure 4.

The dimensions of the conversion reactor are $1.66 \mathrm{~m}$ long and $4.5 \mathrm{~cm}$. radius. It contains a vessel of $100 \mathrm{~mm}$ long and $20 \mathrm{~mm}$ wide, with $5 \mathrm{~g}$. of $\mathrm{UO}_{3}$ inside. From the right end, it will enter a mixture of $\mathrm{H}_{2} / \mathrm{N}_{2}$ gases with a flow of $2.5 \mathrm{~L} / \mathrm{min}$, where hydrogen concentrations are of $0.25 \mathrm{M}, 0.5 \mathrm{M}$ and $0.75 \mathrm{M}$. Hydrogen is stored in a special containment room and its feed rate is controlled with a pressure gauge. The $\mathrm{H}_{2} / \mathrm{N}_{2}$ gas mixture is feeded through the upper section, and its composition is controlled with the valves shown in Figure 4. In the right section of the conversion reactor, the $\mathrm{UO}_{3}$ reduction was carried out. The temperature range will be set at $500^{\circ} \mathrm{C}$, $600^{\circ} \mathrm{C}$ and $700^{\circ} \mathrm{C}$. The middle section of the reactor was insulated to prevent heat loss from the system. The left section, where calcinations take place, was provided with a resistance, which remains at a constant drying temperature of $400^{\circ} \mathrm{C}$. In the left end, two $\mathrm{P}_{2} \mathrm{O}_{5}$ columns capture the water steam generated due to reactions (2) and (3). The results obtained for the reduction kinetics will be determined based on the difference in weight of the columns at the beginning and the end of each experiment. Once each experience was finished, in order to prevent the escape of the residual hydrogen, it is transported outside the $\mathrm{P}_{2} \mathrm{O}_{5}$ columns and slowly burned under a special bell, outside the reactor, to prevent accidents during the experience. 


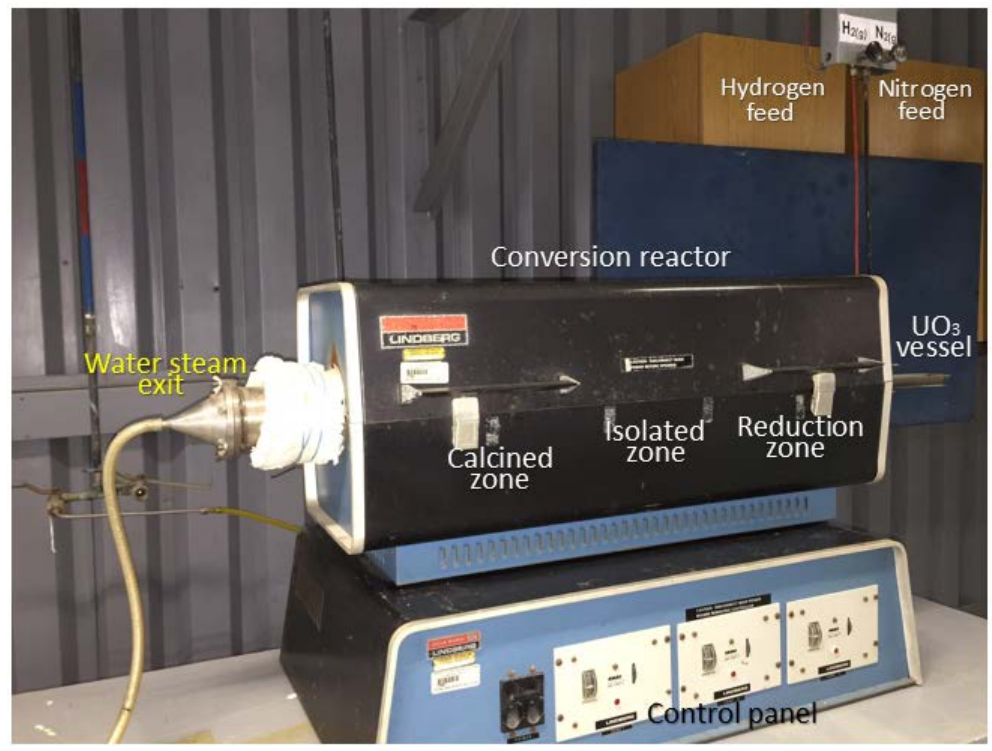

Figure 4. Reactor used for work experience.

\section{Results and Discussions}

The main results for each experiment are shown in Figure 5 and Figure 6.

From Figure 5, it can be seen the influence of temperature on the reduction of $\mathrm{UO}_{3}$ to $\mathrm{UO}_{2}$. Initially, it is expected that the overall kinetic process improve at higher temperatures. However, that is not the case for this work system. The reason for the occurrence of this phenomenon is based on the several uranium oxide compounds formed as intermediate stages and their oxidation states for each one of them.

According to other authors [9], the first compound of uranium oxide formed from the hydrogen reduction of $\mathrm{UO}_{3}, \mathrm{U}_{3} \mathrm{O}_{8}$, consists of uranium atoms with different oxidation states: one having the value (+4), while the other two $(+6)$. This means that hydrogen, by reducing the uranium trioxide, form networks of uranium dioxide and uranium trioxide. In the case of $\mathrm{U}_{3} \mathrm{O}_{8}$ :

$$
\mathrm{U}_{3} \mathrm{O}_{8}=2 \mathrm{UO}_{3} * \mathrm{UO}_{2}
$$

As the process go through, the $\mathrm{U}_{3} \mathrm{O}_{8}$ reduction continues to form the uranium oxide $\mathrm{U}_{3} \mathrm{O}_{7}$. This latter compound has oxidation state $(+5)$ in its structure [10], which is unstable under these temperature conditions. According to papers concerning touranium conversion [1], this oxide, at temperatures above $250^{\circ} \mathrm{C}$, undergoes a dismutation reaction, where this compound is oxidized and reduced at the same time, according to Equation (5):

$$
\mathrm{U}_{3} \mathrm{O}_{7}=\mathrm{U}_{3} \mathrm{O}_{8}+\mathrm{U}_{4} \mathrm{O}_{9}
$$

For $\mathrm{U}_{4} \mathrm{O}_{9}$ compounds, other studies [11] indicate it has 2 uranium ions in oxidation state (+4) and the other 2 in oxidation state (+5). Consequently, because of its instability in these conditions, it will be quickly reduced to $\mathrm{UO}_{2}$. However, oxidation of $\mathrm{U}_{3} \mathrm{O}_{7}$ to $\mathrm{U}_{3} \mathrm{O}_{8}$ at high temperatures $\left(600^{\circ} \mathrm{C}-700^{\circ} \mathrm{C}\right)$, decreases the performance of the overall reaction and forces the system to run for longer times.

In consequence, if the temperature of the system is very high, the oxide $\mathrm{U}_{3} \mathrm{O}_{7}$ can again become $\mathrm{U}_{3} \mathrm{O}_{8}$, which gradually decrease the rate of conversion of $\mathrm{UO}_{3}$. Therefore, for this process the preferred temperatures are $500^{\circ} \mathrm{C}-600^{\circ} \mathrm{C}$.

With respect to the hydrogen concentration in the feed flow of Figure 6, it is possible to conclude that the rate-controlling step is the hydrogen diffusion into the gas-uranium trioxide concentrate interface, because at concentrations of $0.25 \mathrm{M} \mathrm{H}_{2}$, the transformed fraction of $\mathrm{UO}_{3}$ to $\mathrm{UO}_{2}$ reach a value of $80 \%$ in about 15 minutes. However, at hydrogen pressures of $0.5 \mathrm{M}$ to $0.75 \mathrm{M}$, after $5 \mathrm{~min}$ of starting the process, the transformed fraction reaches values above $90 \%$.

Considering this issue, it will set the influence of both variables in the kinetics of reduction of $\mathrm{UO}_{3}$ to $\mathrm{UO}_{2}$, along with the unconverted $\mathrm{UO}_{3}$ solid. For this study, based on the results of Figure 5 and Figure 6, the kinetics of reduction of $\mathrm{UO}_{3}$ is determined by Equation (6): 


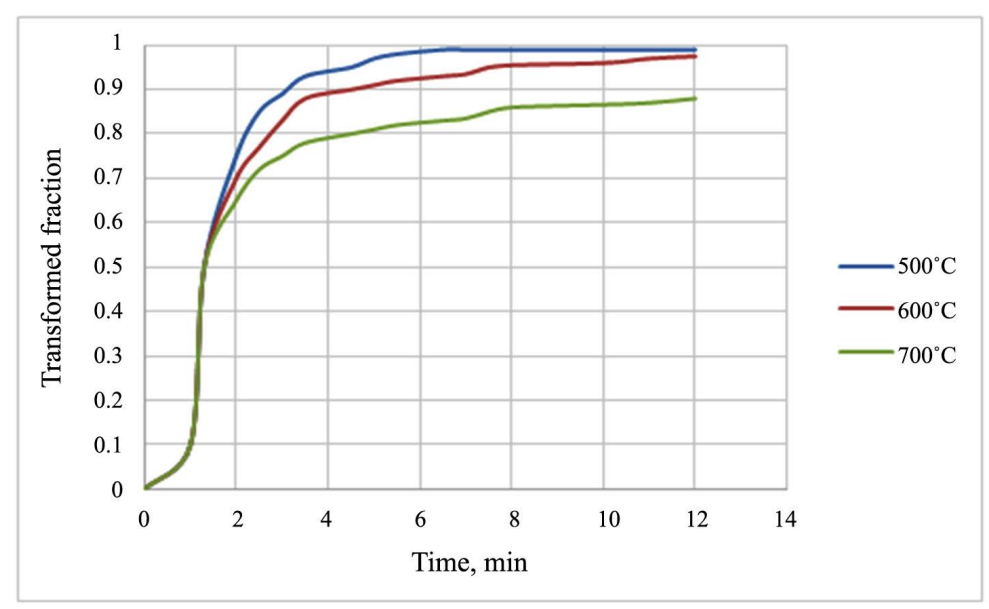

Figure 5. Transformed fraction for reduction from $\mathrm{UO}_{3}$ to $\mathrm{UO}_{2}$.

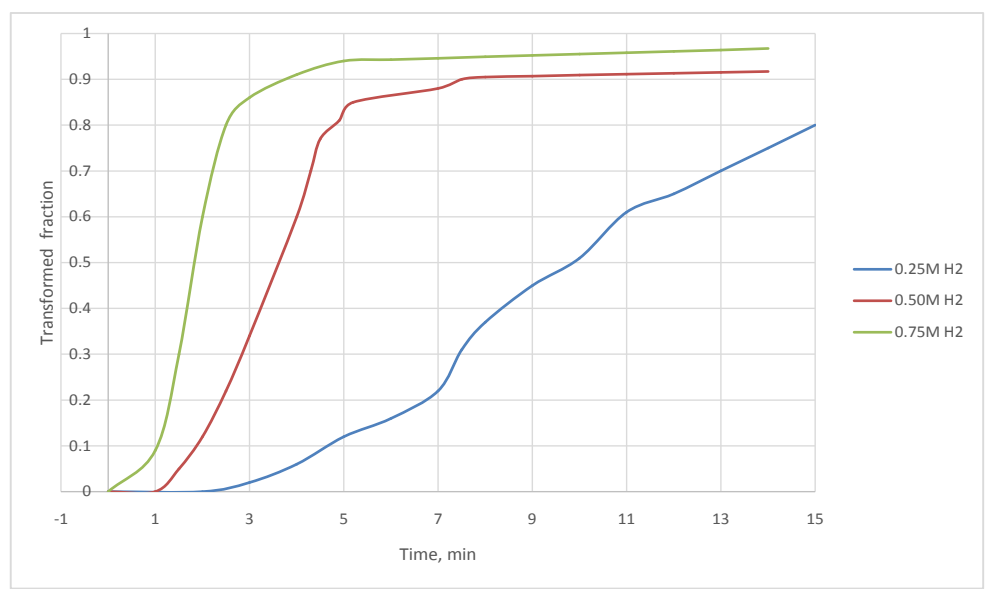

Figure 6. Influence of the hydrogen pressure in the reduction kinetics of uranium trioxide.

$$
\frac{\partial y}{\partial t}=k^{\prime} *(1-y)^{m} *\left(\mathrm{pH}_{2}\right)^{n} * \exp \left(\frac{-E_{a}}{R^{*} T}\right)
$$

where:

$\frac{\partial y}{\partial t}$ : Conversion rate of moles of $\mathrm{UO}_{3}$;

$y$ : Conversion of $\mathrm{UO}_{3}$;

$m$ : reaction order regarding to unconverted $\mathrm{UO}_{3}$ fraction;

$\mathrm{pH}_{2}$ : Hydrogen partial pressure;

$n$ : reaction order regarding to hydrogen partial pressure;

$k^{\prime}$ : Proportionality constant reaction kinetics;

$E_{a}$ : Activation energy system;

$T$ : Temperature;

$R$ : Universal gas constant.

The results for the tests of reaction rate studies for $\mathrm{UO}_{3}$ concentrates are shown in Table 1.

\section{Results First Stage: Reduction of $\mathrm{UO}_{3}$ to $\mathrm{U}_{3} \mathrm{O}_{8}$}

According to Table 1, the reaction order with respect to hydrogen is constant, because of the absence of inter- 
mediate compounds in the formation of $\mathrm{U}_{3} \mathrm{O}_{8}$.

Form Table 2, the value of the activation energy for the first stage is $96,799 \mathrm{kcal} / \mathrm{mol}$. This value shows that the process is highly dependent on temperature.

From Table 3, it is possible to observe that the reaction order for this parameter is negative or very close to zero. Consequently, the reaction kinetics is independent of the fraction of unconverted solid. This is because $\mathrm{UO}_{3}$ concentrate has a high surface area per volume unit, and under these working conditions, these kinds of processes must always be controlled by the diffusion of hydrogen from the boundary layer to the surface of the uranium trioxide.

Accordingly, the equation modeling the reduction kinetics of $\mathrm{UO}_{3}$ to $\mathrm{U}_{3} \mathrm{O}_{8}$ for the ideal working range $\left(500^{\circ} \mathrm{C}\right.$ $\left.-600^{\circ} \mathrm{C}\right)$ is:

$$
1^{\text {st }} \text { stage }: \frac{\partial y}{\partial t}=6.66 * 10^{5} *\left(\mathrm{pH}_{2}\right)^{1.17} * \exp \left(\frac{-96799}{R * T}\right)
$$

\section{Results Second Stage: Reduction of $\mathrm{U}_{3} \mathrm{O}_{8}$ to $\mathrm{UO}_{2}$}

From Table 4, the value of the activation energy in accordance with this data is $203,693 \mathrm{kcal} / \mathrm{mol}$, indicating that the second stage reduction is much more sensitive to temperature than the first stage.

From Table 5 and Figure 7, it is possible to observe that the reaction order is variable for the hydrogen pressure and the unconverted solid in the working system. This is because, unlike the case of the first stage, the surface available for reaction is variable, because of the presence of the side reaction (5). At greater presence of

Table 1. Reaction order with respect to hydrogen.

\begin{tabular}{cc}
\hline $\mathrm{T}\left({ }^{\circ} \mathrm{C}\right)$ & $\mathrm{N}$ \\
\hline 400 & 0.57 \\
500 & 1.16 \\
600 & 1.12 \\
700 & 0.69 \\
\hline
\end{tabular}

Table 2. Values for the determination of the activation energy of the reduction reaction.

\begin{tabular}{cccc}
\hline $\mathrm{T}\left({ }^{\circ} \mathrm{C}\right)$ & $1 / \mathrm{T}\left({ }^{\circ} \mathrm{K}^{-1}\right)$ & $\mathrm{K}$ & $\operatorname{Ln}(\mathrm{k})$ \\
\hline 400 & $1.49 \mathrm{E}-03$ & 0.04 & -3.22 \\
500 & $1.29 \mathrm{E}-03$ & 2.35 & 0.85 \\
\hline
\end{tabular}

Table 3. Reaction order with respect to the unconverted solid.

\begin{tabular}{ccc}
\hline $\mathrm{T}\left({ }^{\circ} \mathrm{C}\right)$ & $\mathrm{H}_{2}$ Molar fraction & Reactionorder \\
500 & 0.25 & 0.13 \\
500 & 0.50 & 0.04 \\
500 & 0.75 & -0.06 \\
600 & 0.25 & 0.02 \\
600 & 0.50 & 0.04 \\
600 & 0.75 & -0.05 \\
700 & 0.25 & -0.19 \\
700 & 0.50 & -0.32 \\
700 & 0.75 & -0.35 \\
\hline
\end{tabular}




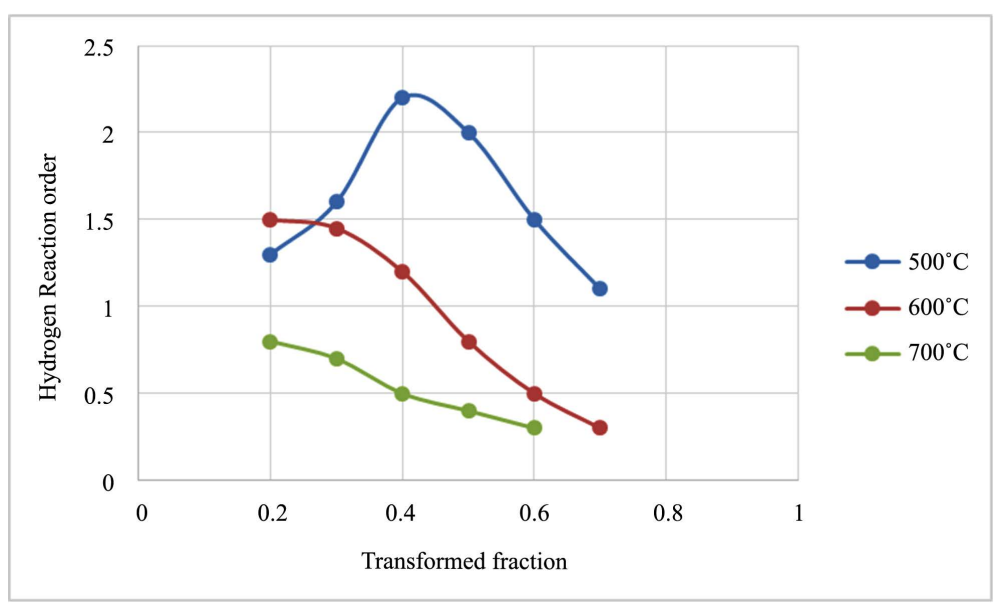

Figure 7. Reaction order with respect to hydrogen.

Table 4. Activation energy of the reduction reaction.

\begin{tabular}{cccc}
\hline $\mathrm{T}\left({ }^{\circ} \mathrm{C}\right)$ & $1 / \mathrm{T}\left({ }^{\circ} \mathrm{K}^{-1}\right)$ & $\mathrm{K}$ & $\operatorname{Ln}(\mathrm{k})$ \\
\hline 400 & $1.49 \mathrm{E}-03$ & 0.04 & -3.22 \\
500 & $1.29 \mathrm{E}-03$ & 2.35 & 0.85 \\
\hline
\end{tabular}

Table 5. Reaction order with respect to the unconverted solid, second stage.

\begin{tabular}{ccc}
\hline $\mathrm{T}\left({ }^{\circ} \mathrm{C}\right)$ & $\mathrm{H}_{2}$ molar fraction & Reactionorder \\
500 & 0.25 & 0.38 \\
500 & 0.50 & 0.71 \\
500 & 0.75 & 1.13 \\
600 & 0.25 & 0.42 \\
600 & 0.50 & 1.44 \\
600 & 0.75 & 1.62 \\
700 & 0.25 & 0.96 \\
700 & 0.50 & 2.01 \\
700 & 0.75 & 2.63 \\
\hline
\end{tabular}

$\mathrm{U}_{3} \mathrm{O}_{8}$, the greater is the dependency on reaction kinetics respect to both parameters.

From the graphs above, we can conclude that the equation that models the rate of reaction of $\mathrm{U}_{3} \mathrm{O}_{8}$ for the ideal working range $\left(500^{\circ} \mathrm{C}-600^{\circ} \mathrm{C}\right)$ is:

$$
2^{\text {nd }} \text { stage }: \frac{\partial y}{\partial t}=6.7 * 10^{13} *\left(p H_{2}\right)^{1.05} *(1-y)^{0.77} * \exp \left(\frac{-203693}{R * T}\right)
$$

\section{Conclusions}

- Reduction of uranium trioxide to uranium dioxide occurs in two stages: in the first one, the $\mathrm{UO}_{3}$ is reduced to $\mathrm{U}_{3} \mathrm{O}_{8}$ directly, whereas in the second stage, the $\mathrm{U}_{3} \mathrm{O}_{8}$ is reduced to $\mathrm{UO}_{2}$, through various intermediate reactions.

- At temperatures over $600^{\circ} \mathrm{C}$, the intermediate reaction of dismutation of the $\mathrm{U}_{3} \mathrm{O}_{7}$ decreases the overall performance of the global process, which triggers the loss of effective superficial area of reaction. Therefore, the 
main reaction mechanism is the diffusion of the hydrogen inside of the uranium trioxide.

- According to the reaction kinetics for the $\mathrm{UO}_{3}$ reduction (Equation (1)), it mainly depends of hydrogen pressure and working temperature. The effect of both variables benefits the diffusion of hydrogen, stimulating the reaction in the surface of the oxide.

- The rate controlling step for the reduction of $\mathrm{U}_{3} \mathrm{O}_{8}$ to $\mathrm{UO}_{2}$ (Equation (8)), depends besides of the unconverted solid, caused by a decrease in active sites, affecting the chemisorption of hydrogen.

- The optimum operating range of the conversion process is in the range of $500^{\circ} \mathrm{C}-600^{\circ} \mathrm{C}$ and hydrogen concentrations in gaseous solution of $0.75 \mathrm{M}$. These parameters allow reaching higher transformed fraction values in less time.

\section{References}

[1] Cordfunke, E.H.P. (1969) The Chemistry of Uranium. Elsevier Publishing Company, Amsterdam.

[2] Radiochemistry Group of the Royal Science of Chemistry, the Nuclear Fuel Cycle. http://www.rsc.org/images/essay7 tcm18-17769.pdf

[3] Bonini, A., Cabrejas, J., De Lio, L., Dell’Occhio, L., Devida, C. Dupetit, G., Falcón, M., Gauna, A., Gil, D., Guzmán, G., Neuringer, P., Pascale, A. and Stankevicius, A. (1998) Nuclear Fuel Cycle Head-Enriched Uranium Purification and Conversion into Metal. International Reduced Enrichment for Test Reactor Conference, Sao Paulo.

[4] Pourbaix, M. (1974) Atlas of Electrochemical Equilibrium in Aqueous Solutions. National Association of Corrosion Engineers.

[5] Thein, S.M. and Bereolos, P.J. (2000) Thermal Stabilization of ${ }^{233} \mathrm{UO}_{2},{ }^{233} \mathrm{UO}_{3}$, and ${ }^{233} \mathrm{U}_{3} \mathrm{O}_{8}$.

[6] Valdivieso, F., Pijolat, M., Soustelle, M. and Jourde, J. (2000) Reduction of Uranium Oxide $\mathrm{U}_{3} \mathrm{O}_{8}$ into Uranium Dioxide $\mathrm{UO}_{2}$ by Ammonia. In: Solymosi, F. and Rask, O., Eds., 14th International Symposium on the Reactivity of Solids, August 2000, Budapest, Elsevier, 117-122, 141-142.

[7] Fredrickson, J.K., Zachara, J.M., Kennedy, D.W., Liu, C.X., Duff, M.C., Hunter, D.B. and Dohnalkova, A. (2002) Influence of Mn Oxides on the Reduction of Uranium(VI) by the Metal-Reducing Bacterium Shewanella putrefaciens. Geochimica et Cosmochimica Acta, 66, 3247-3262. http://dx.doi.org/10.1016/S0016-7037(02)00928-6

[8] Duff, M.C., Coughlin, J.U. and Hunter, D.B. (2002) Uranium Co-Precipitation with Iron Oxide Minerals. Geochimica et Cosmochimica Acta, 66, 3533-3547.

[9] Zhang, F.X., Lang, M., Wang, J.W., Li, W.X., Sun, K., Prakapenka, V. and Erwing, R.C. (2014) High-pressure $\mathrm{U}_{3} \mathrm{O}_{8}$ with the Fluorite-Type Structure. Journal of Solid State Chemistry, 213, 110-115.

[10] Salbu, B., Janssensb, K., Linda, O.C., Proost, K., Gijsels, L. and Danesi, P.R. (2005) Oxidation States of Uranium in Depleted Uranium Particles from Kuwait. Journal of Environmental Radioactivity, 78, 125-135. http://dx.doi.org/10.1016/j.jenvrad.2004.04.001

[11] Kvashnina, K.O., Butorin, S.M., Martin, P. and Glatzel, P. (2014) The Chemical State of Complex Uranium Oxides. European Synchrotron Radiation Facility, Grenoble. 